\title{
Technology Acceptance in e-Governance: A Case of a Finance Organization
}

\author{
Fatemeh Mohammad Ebrahimzadeh Sepasgozar ${ }^{1, *}$, Usef Ramzani ${ }^{2}$, Sabbar Ebrahimzadeh ${ }^{3}$, \\ Sharifeh Sargolzae ${ }^{4}$ and Samad Sepasgozar ${ }^{5}$ (D) \\ 1 Management Department, Hakim Nezami Institute of Higher Education, Quchan 8719494717, Iran \\ 2 Attar Institute of Higher Education, Razavi Khorasan Province, Mashhad 9177939579, Iran; \\ Usef_ramzani@yahoo.com \\ 3 Department of Law, Quaemshahr Azad University, Qaemshahr 4765161964, Iran; sabbar.ebr@gmail.com \\ 4 Department of Urban Planning, University of Zabol, Zabol 9868114463, Iran; sh.sargolzaei@uoz.ac.ir \\ 5 Faculty of Built Environment, University of New South Wales, Sydney, NSW 2052, Australia; \\ samad.sepasgozar@gmail.com \\ * Correspondence: f.mesepasgozar@gmail.com
}

Received: 28 April 2020; Accepted: 16 June 2020; Published: 29 June 2020

\begin{abstract}
Presently, one of the most critical challenges for e-government and e-banking is the accurate and correct realization of factors that have a significant impact on customer behavior. Without appropriate knowledge of these factors, it would be impossible to predict the level of welcoming toward new services, acquire a competitive advantage, and coordinate marketing programs with the needs of customers. On the other hand, in today's competitive world, banks are obliged to implement new services to retain current customers and attract new ones. This research has been conducted with the goal of identifying influential factors that have an impact on the development of user intentions. The theoretical research model has been designed based on the technology acceptance model (TAM), as well as technology adoption theory, technology dissemination theory, and planned behavior theory. This study adopted an empirical approach to investigate key acceptance factors in a case organization. The statistical population of this research consists of customers and employees in different branches of a financial institution called Mehr bank in Iran. The data was collected by means of questionnaires that were completed by 200 customers and employees who work at Mehr bank or have business relationships with it. Data analysis in descriptive and inferential statistics domains had been done in SPSS and AMOS software, respectively. This paper presents first-hand data analysis of a case study on technology adoption in banking systems in Iran. In addition, structural equations have been used for inferential analysis. The findings of this study confirm the direct impact of "perceived usefulness" and "perceived ease of use" towards user attitudes. In addition, results show that "attitude" and "perceived usefulness" have a direct impact on the development of usage intention in customers. However, the results do not confirm the role of subjective norms on the development of user intent. This study is limited to a selected organization, and the proposed model should be examined by applying it in different contexts.
\end{abstract}

Keywords: Internet banking; e-government; finance; and banking technology; technology adoption; theory of planned behavior; customer attitude

\section{Introduction}

There has been a wide range of new technologies introduced to different businesses (Shirowzhan et al. 2020; Hasibuan and Syahrial 2019). In the current situation of COVID-19, in which most businesses are affected (Yue et al. 2020; Yue et al. 2020) and citizens and employees are encouraged 
or forced to do business remotely from home, the demand for using appropriate technologies is increasing. This experience of the pandemic is a transformative global event that may raise the need for fully online work. While the need for smart systems, including smart city (Sepasgozar et al. 2019), smart real estate (Ullah et al. 2017), e-government (Bailey et al. 2017; Kurfalı et al. 2017; Twizeyimana and Andersson 2019), e-commerce (Gregory et al. 2019; Vakulenko et al. 2019), e-banking (Ramesh et al. 2020; Shankar and Jebarajakirthy 2019), and other digital systems (Sepasgozar et al. 2017), are increasingly reported, the current pandemic has increased the significance of the automation and online systems. However, there is a need to investigate information system behavior in different contexts, and scholars are investigating technology acceptance in different contexts (Hasibuan and Syahrial 2019; Rifat et al. 2019; Rakhmawati and Rusydi 2020; Soeng et al. 2019). Meanwhile, social structures usually hinder the dissemination of innovations. The difference between human tacit knowledge and effective practical solutions should be reduced as much as possible. Both technologies and user behavior are changing over time, and so there is a need to conduct empirical investigations to identify current factors influencing the acceptance of new technology. The gap in the literature mainly concerns the dynamic factors that are changing from time to time in different contexts and communities. Identifying the ways new ideas transferred from resources toward talented recipients and what factors have an impact on the adoption of innovations is necessary for the reduction of this gap (Becerra et al. 2008). Increases in the volume of monetary and financial transactions and simplification of e-commerce in recent decades have led to the gradual substitution of traditional banking systems for electronic ones (e-banking systems). Accordingly, banks have a significant role in increasing e-commerce through the application of modern technologies in the banking industry and moving toward e-banking (Soeng et al. 2019). Thus, this study focuses on banks and will examine their technology user behavior. The main objectives of this study are to investigate the role of perceived usefulness on the creation of customer attitude; to examine the role of ease of use (for banking services) on the creation of customer attitude; to investigate the role of perceived control on the creation of usage intention in customers; to examine subjective norms on the creation of usage intention in customers; to examine customer attitude in the creation of usage intention in customers; and finally to investigate the role of perceived usefulness on the cryeation of usage intention in customers.

On the other hand, banks proceed toward the implementation of modern technologies to move ahead of other competitors in highly intense financial markets and provide better services for their customers. It is one of the main elements for guaranteeing organization successes in today's competitive world, which requires the development of marketing thinking/philosophy and customer orientation. It looks like the importance of using modern technologies in the banking industry is obvious to everybody, but what is less noticed in our country is adoption and settlement toward these technologies by society and users and quitting traditional ones.

In the current information and communication technology (ICT) research, e-banking is a subtitle of e-government. Electronic governance aims at improving information and service delivery of public-sector institutions. It simply involves the use of online or several digital mediums for public service delivery and information sharing to citizens, businesses, and among its agencies. E-governance presents an era of modernity, innovation, and flexibility towards efficient and quality public service delivery (Osei-Kojo 2017). Actually, e-government is a necessary process in urban management, as is becoming increasingly evident given the trends of the aging population, of overcrowding of the cities, of maintaining high unemployment rates of youth or elderly population, and finally of increasing the efficiency of public services. E-Government is commonly conceptualized as government use of ICTs combined with organizational change to improve the structures and operations of government (Twizeyimana and Andersson 2019). E-governance refers to "the use of ICTs, and particularly the Internet, as a tool to achieve better government". Moreover, it can be defined as continuous optimization of service delivery, constituency participation, and governance by transforming internal and external relationships through technology, the Internet, and new media (Adjei-Bamfo et al. 2019). 
Since there is a continuous expansion in applications of communication and information technologies in the modern world, which increases their penetration in human life, banks inevitably move toward the development of Internet banking services. Quick and mind-blowing advances in this field led banks to the most modern technologies to acquire the satisfaction of their customers. One of these new technologies is Internet banking. Banks cannot guarantee that their return on investment and financial development in previous years will be continued in the upcoming years. Banks need to make themselves bold and different, which requires inimitable capabilities. It can be achieved only through unusual and unconventional innovations for compatibility and response to market demand (Kaabachi et al. 2019).

The adoption of new technologies in the field of banking by customers does not turn around easily. Generally, substituting traditional banking with modern banking procedures requires investigation of customer behaviors, needs, and expectations. Various models have been considered in previous studies; some of the most referred-to models consist of behavioral control theory, technology adoption, and technology dissemination. Part of modern banking totally depends on the Internet. Internet banking is considered to be part of e-commerce in available definitions (Martins et al. 2014).

By having a quick look toward Internet banking systems, it can be seen that communication and information technologies have a wide range of applications/impacts on the banking industry. On the other hand, banks have also tried to make the required connections toward global communication systems to keep their current position in such conditions. Modern technologies have led to the creation of new products and services in the field of financial management, which has provided the basis for exponential growth and development of banks. Our life is quite familiar with new communication and information technologies such as websites, e-mails, instant messages, SMS, etc. Financial organizations typically use one or more than one type of these communication channels to deliver banking information to their customers. The main goal of such services is in-time and adequate notification to customers about the details of their bank accounts and providing banking services to them anytime and anywhere. The application of information technology in banking services lets customers be informed about the details of their bank accounts anywhere and anytime, receive financial services, and carry out their transactions (Bernanke et al. 2018).

Presently, the appearance of the Internet and informing capabilities based on wireless technologies has led to significant use of banking services. These conditions led to the reinforcement of the banking system and changed the way banking services are used by customers. There are several reasons that justify the need to use digital technologies such as the increasing number of banks, the wide range of services that they offer, and the need for customers for the acquisition of online services without physical presence. The introduction of the Internet in the field of banking has led to the establishment of official bank websites. These websites provide a wide range of banking services for their customers, which are simply activated by connecting to the Internet and entering the websites. They can perform different banking operations in such virtual environments. However, the Internet would definitely have its unique issues, problems, and benefits just as with any other technology (Rahman et al. 2017).

Meanwhile, the development of new concepts such as electronic money transfer, e-money, smart cards, e-payment, etc., which are requirements in a modern business environment, have led to a new phenomenon which is called e-banking. On the other hand, the general method for offering banking services has been revolutionized with the development of the Internet and smartphones. E-banking has freed banks from temporal and spatial limitations. They can provide their services to their customers day and night. Generally, e-banking can be considered to have far-reaching usage of advanced communications and network technology for the proper integration of all banking activities. E-commerce is one of the best examples of the application of information and communication technologies for the realization of economic objectives. The application of this technology has led to economic development, improvements in productivity, and facilitating the convergence of countries (especially developing ones) in the global economy. ICT has improved the competitiveness of businesses and led to the creation of job opportunities (Sedik et al. 2019). 
This paper first reviews the background of a finance organization; second, it examines the literature; next, it develops the proposed model and hypotheses. Then, the data will be analyzed, and the results are discussed.

\section{Theoretical Background}

\subsection{Finance Organization}

The development and application of information technology in different fields, especially the banking industry, is the outcome of its capabilities, which are highly accepted in today's business world. Third-millennium mankind tries to separate itself from traditional patterns of business to accelerate the development and operational procedures of information technology in different sectors of social structure and provides a new pattern that is in accordance with necessities of the modern information era. Mehr bank directed its efforts toward investment in the field of modern technologies as quickly as possible just like any other service provider in the field of the banking industry; it has performed a series of orchestrated efforts in recent years in order to control the costs, attract new customers, and acknowledge customer expectations. The implementation of such technologies (Internet banking, telephone banking, ATMs, etc.) is a strategic priority toward meeting its objectives. The customer is the key to the success of any organization or commercial activity. The credibility of any successful organization has been acquired based on its long-term relationships with customers. Providing appropriate services is the most important factor in ensuring their satisfaction and loyalty. The organization which designed one of its practical objectives toward the preparation of worthy services according to the needs and expectations of its customer can guarantee its success based on other business principles. Offering appropriate services is only possible through the identification of customer needs, interests, abilities, and expectations. The collection of such information in a comprehensive manner helps organizations to provide services in an efficient manner according to the needs and expectations of customers (Chu et al. 2012).

E-banking can be defined as follows: providing financial and banking services through the Internet and electronic networks (Kumar 2020; Syniavska et al. 2019; Karunakaran 2019). It has drawn the attention of many researchers as one of the most critical infrastructures of e-commerce. Many of them devoted their time to extending the fundamentals of e-banking. E-banking has taken a giant leap in recent years, and there is no doubt that having an efficient banking system that can compete with accuracy, speed, and technology of paramount banks on a global scale is a necessity for entering global markets and membership in world trade organization (WTO).

\subsection{A Brief Review of Technology Acceptance Theories}

Many papers focus on how new technologies, such as tools and devices of e-banking, are accepted by users. For the first time, Davis, in 1986 in his doctoral thesis, proposed a model called the technology acceptance model (TAM) to predict the decision of users about acceptance of technologies (Davis 1993; Sepasgozar et al. 2016). TAM is a basis for technology acceptance models and is used in different fields (Sepasgozar et al. 2016). Many papers always try to examine the dimensions of technology acceptance from the perspective of users in different societies. The results of these papers show that the variables affecting the acceptance of technology in different societies are not the same, and the TAMs should always be modified (Sepasgozar et al. 2019). TAM2 is a semi-developed model of TAM, which illustrated the constructs of perceived usefulness, such as subjective norm, image, and job relevance. These types of constructs indicate that using new technology will be more useful for users who would accept the new technology to use or reject it (Sepasgozar et al. 2019). The results of studies on technology acceptance have shown that there are other constructs affecting perceived ease of use, too. Some of them are computer self-efficacy, computer anxiety, and computer playfulness. Therefore, in TAM3, which is more developed than TAM2, the added constructs illustrate using new technology will help people to live more easily than before. This developed model needs to be adopted for use 
in other fields of employing technology such as transportation, urban planning, and infrastructure management fields. Developing models of TAM would provide an excellent basis to decision-makers and managers in various fields, especially urban managers. A key purpose of TAM is to determine the individual IT adoption and use. Figure 1 shows the final version of TAM (TAM3), which consists of all their constructs.

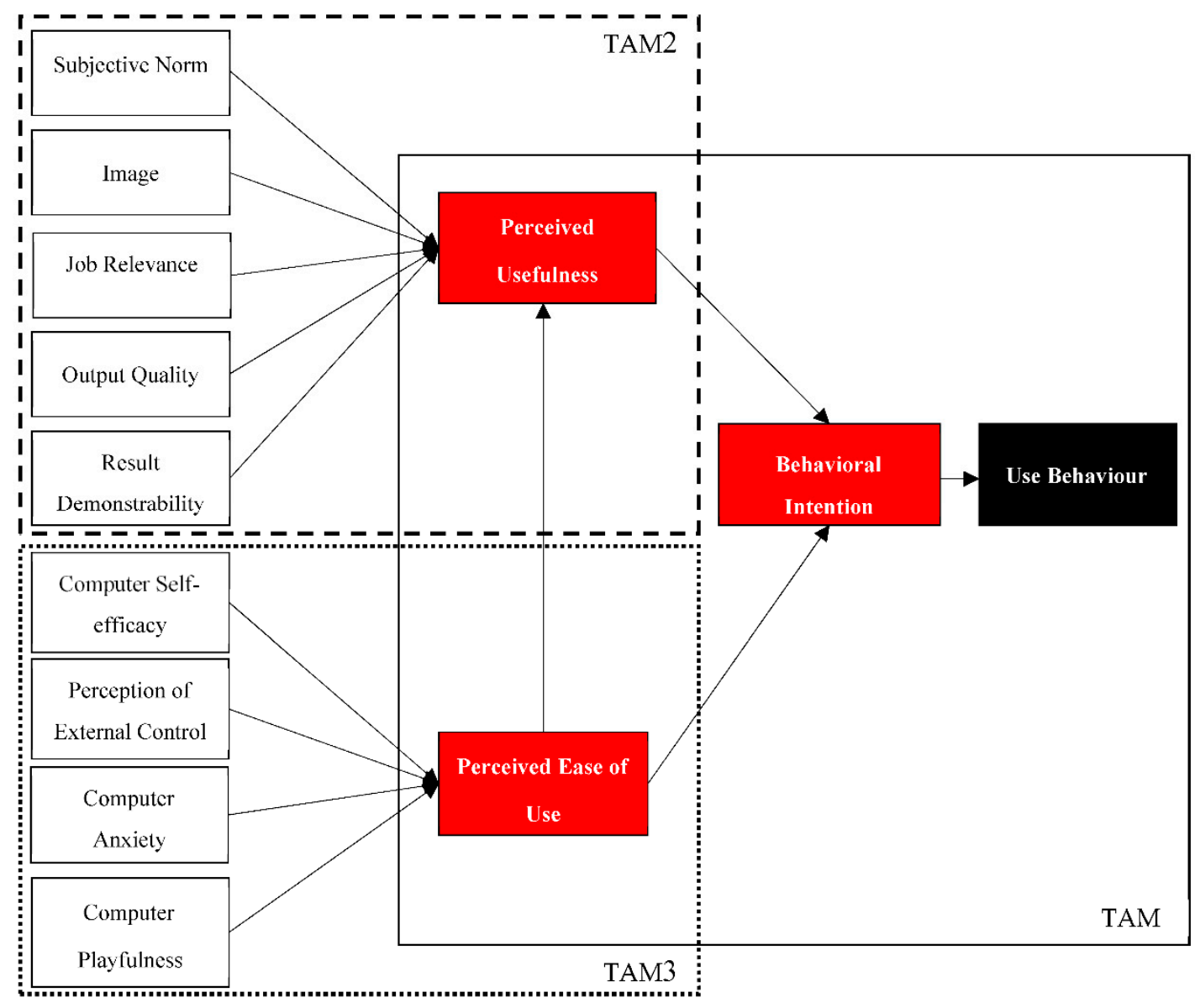

Figure 1. A summary of added constructs in different versions of Technology Acceptance Models.

The theory of planned behavior postulates different conceptually independent determinants of intentions (Ajzen and Fishbein 1977). As shown in Figure 2, the first factor is the attitude toward the behavior and refers to the degree to which a person has a favorable or unfavorable evaluation or appraisal of the behavior in question. The second predictor is a social factor termed subjective norm; it refers to the perceived social pressure to perform or not to perform the behavior. The third antecedent of intention is the degree of perceived behavioral control, which, as we saw earlier, refers to the perceived ease or difficulty of performing the behavior, and it is assumed to reflect past experience as well as anticipated impediments and obstacles (Ajzen 1991).

\subsection{The Role of Theories in the Finance Organization}

Davis's e-banking implementation model consists of variables such as security and privacy, perceived usefulness, perceived ease of use, and reluctance toward change. Results of previous research show that perceived ease of use has a significant impact on the intention of usage, which might be direct or indirect (through perceived usefulness). In fact, information technology, which is easy to use, is less threatening to people. In the field of financial resource allocation, many factors may have an impact on the allocation of banks' monetary resources. Identification and analysis of different types of factors and understanding their relationship with the successful allocation of financial resources 
in banks is one of the most important issues in this field. Presently, different banks have different situations and conditions which lead to unequal effective factors in the allocation of monetary resources. The allocation of resources consists of methods that are followed by banks to attract customers and encourage them to invest their resources in banks. In the past, banks and financial institutions absorbed financial resources through banking operations, which have been substituted with modern methods in the current situation.

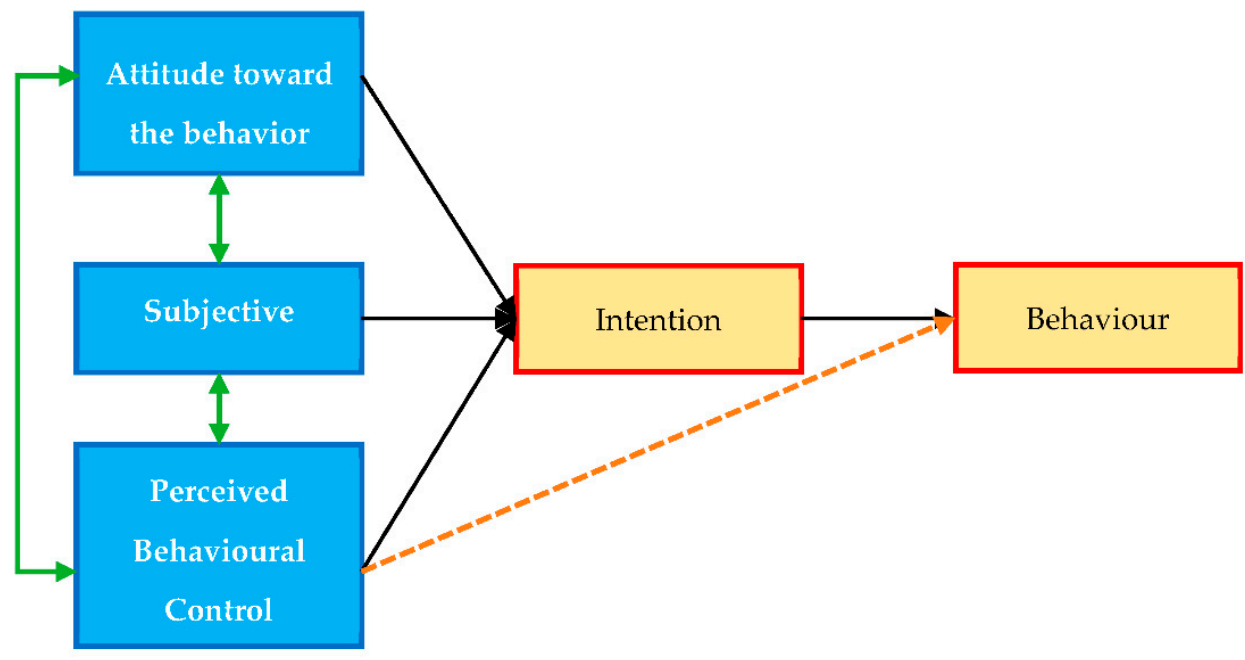

Figure 2. Theory of planned behavior.

The steady growth of globalization and competition has led to significant changes in fields such as business, bank management, and government, so traditional methods changed to modern ones. There is no argument that innovative and superior organizations should equip themselves with the most advanced technologies and technical skills to have an appropriate response to future technological and infrastructure variations. Technologies usually applied in an organizational context to change their working condition and to improve their activities and processes. The implementation of technologies is done based on different models. However, the point which had been paid attention to the least is the adoption and compatibility of users with these technologies and leaving traditional ones behind.

Banks try to reduce the level of customer reference, congestion, and crowd, which has led to lower service quality. The importance of current research for banks lies in the fact that previous investigations on the development of modern technologies have tried to identify factors that have the highest impact on adoption and compatibility toward such technologies. There are many types of research in this field inside the country, but the current one is different from the statistical population perspective and the selected case organization, in the first place. In addition, this investigation tries to consider different factors from fundamental theories of planned behavior theory, TAM in one comprehensive framework, and then tests it on the selected statistical population.

Vast application and adoption of the Internet and future structure of the banking industry has led to retail banking services in which there are a few banks in each cluster that provide services, and most of the banks consider the Internet as the main distribution channel. Predicting the next behavior of customers is one of the most important aspects of successful marketing solutions. Therefore, it is critical for banks to understand customer behavior and their corresponding impact. E-banking can be defined as the accessibility of banking services for customers through secure intermediaries without the necessity of a physical presence in branches of banks. Higher availability of global networks has led to a revolution in the field of communications, which saves customers money and time, and improves their access to various channels for the execution of banking procedures. Presently, modern and Internet-based transactions have substituted traditional monetary transactions, and international transactions are performed through the Internet (Heng 2004). 
Presently, customers have more opportunities for comparing the services of different banks, and the misjudgment about banks is provided based on their perceived usefulness in solving the problems and developing business relationships. In Iran and many developed countries all over the world, quick operations and minimum waste of time are considered to be the most important factors for ensuring success in banking competition. Customers as the main element for evaluation of banking competitiveness consider a high value for technology, speed, and banks' technical capabilities in the same arrangement as the most important factors for their prioritization. Modern banking requires new techniques, efficient customer orientation, presentation of new technologies, and procurement of customized services for customers. In fact, any bank that has a better performance in these fields can be successful in the acquisition of more resources and higher stability, creating efficiency in its lifecycle and ensuring its survival; e-banking is the only choice toward these banks for the realization of such goals (Takele and Sira 2013).

Banks in developing countries usually investigate the available services in the banking industry of developed countries and try to imitate them and provide similar services, but such investigation lacks further depth and analysis, and this situation leads to the representation of defective services toward their customers (Petrou 2007).

\section{A Review of Models and Hypotheses Development}

The goal of (Marakarkandy et al. 2017) research was identifying the impact of antecedent subjective norm, mental image, banking initiatives, self-efficiency of Internet banking, perceived efficiency of Internet usage, trust, perceived risk, governmental support, and authorization toward current structures on ATM model. The statistical sample of their research consists of 300 customers in the Internet banking sector. The findings confirmed the proposed model significantly. The effect of factors such as subjective norms, mental image, bank initiatives, self-efficiency of Internet banking, perceived efficiency of Internet usage, trust, perceived risk, and governmental support toward adoption of Internet banking had been confirmed, respectively.

Jamshidi and Hussin (2016) focused on predicting influential factors for support of a customized Islamic credit card as a new e-banking service: the integration of TAM with religiosity and perceived trust. The goal of their research was to suggest a practical model for easier adoption of the Islamic credit card; the statistical population of their research consists of 327 of bank customers. Results showed that perceived religiosity increases predicted usage intention. In fact, the effect of perceived usefulness, ease of use, and perceived attitude is improved by the addition of tendency toward religiosity.

Mansour (2016) examined customer attitudes toward Islamic e-banking services by using a case study of Sudan. The goal of their research was to investigate the attitudes of users toward electronic banking technologies: (1) ATMs, (2) mobile banking, and (3) online banking. The statistical sample consisted of 132 people in sectors of the banking industry. TAM had been selected as the original pattern. This study showed that the attitude of customers toward various banking technologies is not different and influenced by a wide range of factors. Results showed that customers who use ATMs are influenced by convenience, ease of use, and quality of services; meanwhile, credibility does not have a significant impact. It seems as if mobile users are usually affected by benefits, ease of use, and quality of services. Finally, Internet banking customers are influenced by benefits, ease of use, and credibility of systems. In all the models, the attitude has a mediating role in the behavioral intentions of customers. Thus, in this study, the following hypotheses will be considered:

Hypothesis 1 (H1). Perceived usefulness has a significant and positive relationship with attitude.

Hypothesis 2 (H2). Perceived ease of use has a significant and positive relationship with attitude.

Tam and Oliveira (2017) investigated personal understandings toward the application of mobile banking based on Delone and McLean's model (Delone and McLean 2003), and the mediating role of 
personal culture. The goal of this research is to identify the impacts of cultural factors on the adoption of mobile banking. The statistical population of their research consists of 354 users of mobile banking services in southern Europe, which were contacted via e-mail questionnaires. Results show that user usage and satisfaction are significant antecedents of personal actions. In addition, the mediating role of personal characteristics on the relationship between usage intention and user satisfaction had been confirmed too. The system, information, and quality of services have a positive impact on customer satisfaction.

Rigopoulou and Chaniotakis (Rigopoulou et al. 2017) focused on advanced technology adoption models for the prediction of smartphones in the youth population of Greece. The goal of such research was to investigate potential factors that have an impact on the intention of usage in young people of Greece; it relates to innovation dissemination theory. The statistical sample consisted of 310 young customers in Greece's banking industry. According to results, the intention to buy smartphones was influenced by factors such as perceived usefulness, perceived ease of use, and monetary values. In addition, monetary value is influenced by social norms, which are considered to be social values. Perceived usefulness was also influenced by compatibility factors; perceived ease of use is under the influence of perceived behavioral control. Thus, in this study, the following hypotheses will be considered:

Hypothesis 3 (H3). Behavioral control has a significant and positive relationship with usage intention.

Since the focus of the current study is an organization in a developing country, some other key factors should be considered, such as subjective norms and behavioral control. Therefore, a relevant theory called planned behavior developed by Ajzen (1991) is also considered to be a theoretical lens of this study. The final proposed model is shown in Figure 3, including positive relationships between constructs as a set of hypotheses for investigation.

Hypothesis 4 (H4). Subjective norm has a significant and positive relationship with usage intention.

Hypothesis 5 (H5). Attitude has a significant and positive relationship with usage intention.

Hypothesis 6 (H6). Perceived usefulness has a significant and positive relationship with usage intention.

The conceptual model of research had been provided by the integration of planned behavior, and TAM. Previous studies (Sepasgozar et al. 2016; Jamshidi and Hussin 2016; Rigopoulou et al. 2017; Kwateng et al. 2019; McNamara and Sepasgozar 2020) had been reviewed, and after removing the overlapping dimensions in them, the final integrated model had been proposed. According to the proposed model, which has been achieved by a combination of two fundamental theories, customer attitudes, subjective norms, behavioral control, and perceived usefulness lead to the creation of purchasing intention in customers. In addition, perceived ease of use and perceived usefulness have a significant impact on the development of customer attitudes. The research's conceptual model is shown in Figure 3. 


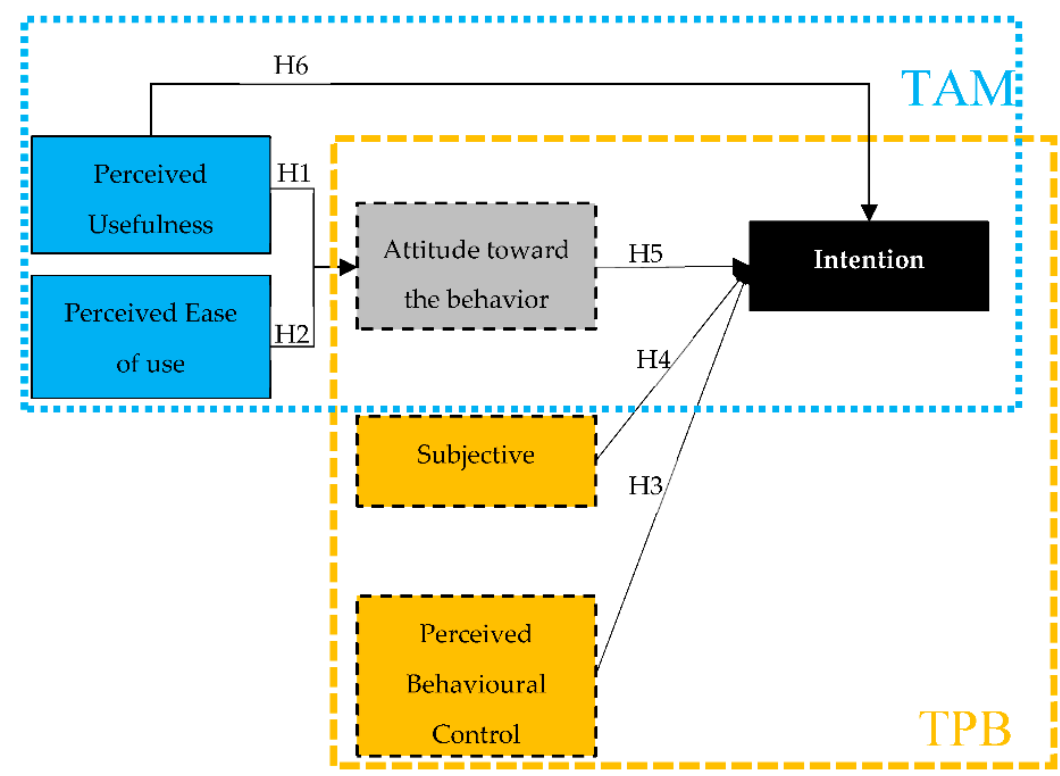

Figure 3. The technology acceptance conceptual model for further investigation.

\section{Data Analysis}

\subsection{Statistical Population and Sample}

The current research was performed in selected branches of Mehr bank in northern Khorasan province (spatial domain). This research is practical from a goal perspective since the necessity of testing a theoretical hypothesis in real situations and conflicts is clear. The subject of this study is focused on the behavior of customers. It is descriptive-a survey research. It tries to describe different events, subjects, and issues in an objective, realistic, and organized way. It is categorized as correlation research according to the type of existing relationships between customers.

The statistical population of the current research consists of customers who are accessible at Mehr bank in northern Khorasan province. They use the bank's services occasionally or continuously. The sampling method for the current research is convenience sampling. Since the size of the population and its variance are unknown, the size of the sample has been estimated according to the number of items (questions) in the questionnaire. The five-point Likert scale is common in this style of technology acceptance surveys and thus was adopted in the present study. The questions from the literature of technology acceptance models such as Sepasgozar, Hawken (Sepasgozar et al. 2019) and Scherer, Siddiq (Scherer et al. 2019) were considered for designing the questionnaire.

According to the above explanations and based on the 21 items in the questionnaire, the required sample is something between 105-315 questionnaires. Finally, 200 questionnaires had been completed and collected for further analysis. Table 1 shows the demographic data of the sample.

Table 1. Demographic data of the sample.

\begin{tabular}{llcc}
\hline \multicolumn{2}{c}{ The Demographic Characteristics } & Frequency & Percentage \\
\hline \multirow{3}{*}{ Gender } & Male & 126 & $63 \%$ \\
\cline { 2 - 4 } & Female & 74 & $37 \%$ \\
\cline { 2 - 4 } & Total & 200 & $100 \%$ \\
\hline \multirow{3}{*}{ Age } & Less than 25 & 16 & $8 \%$ \\
\cline { 2 - 4 } & $26-35$ & 112 & $56 \%$ \\
\cline { 2 - 4 } & $36-45$ & 72 & $36 \%$ \\
\cline { 2 - 4 } & Total & 200 & $100 \%$ \\
\hline
\end{tabular}


Table 1. Cont.

\begin{tabular}{llcc}
\hline \multirow{2}{*}{ The Demographic Characteristics } & Frequency & Percentage \\
\hline \multirow{4}{*}{ Education } & Associates degree & 20 & $10 \%$ \\
\cline { 2 - 4 } & Bachelors & 48 & $24 \%$ \\
\cline { 2 - 4 } & Masters & 114 & $57 \%$ \\
\cline { 2 - 4 } & PhD & 18 & $9 \%$ \\
\cline { 2 - 4 } & Total & 200 & $100 \%$ \\
\hline \multirow{5}{*}{ Earnings } & Less than 600,000 & 40 & $20 \%$ \\
\cline { 2 - 4 } & $600,000-1,000,000$ & 32 & $16 \%$ \\
\cline { 2 - 4 } & $1,000,000-2,000,000$ & 56 & $28 \%$ \\
\cline { 2 - 4 } & $2,000,000-3,000,000$ & 33 & $16 / 5 \%$ \\
\cline { 2 - 4 } & More than 3,000,000 & 32 & $16 \%$ \\
\cline { 2 - 4 } & total & 200 & $100 \%$ \\
\hline
\end{tabular}

The following is a comparison between the demographic characteristics of the statistical sample using the graphs presented in Figure 4.

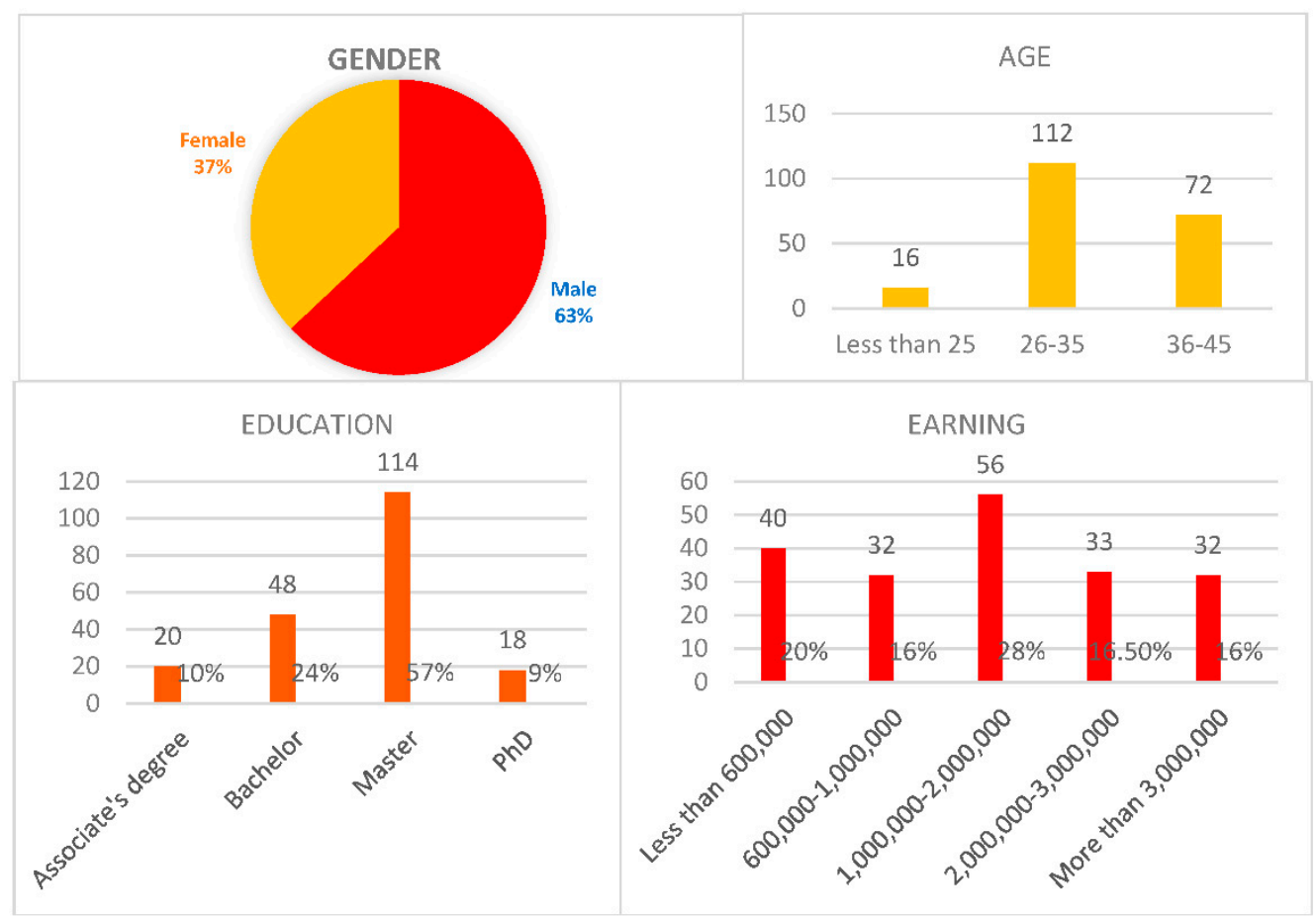

Figure 4. Gender, Age, Education, and Earning of a statistical sample.

\subsection{Composite Reliability}

The reliability of the questionnaire (51 questionnaires) is measured by two criteria: (1) Cronbach's alpha reliability, and (2) composite reliability. Cronbach's alpha indicates the reliability of the questions in determining the appropriate combination of its own. Composite reliability's coefficient distinguishes the correlation coefficient of questions in one dimension than another's for fitting adequate measurement models (Fornell and Larcker 1981). Although Cronbach's alpha (Cronbach 1951), and composite reliability should be greater than 0.7 (Sepasgozar et al. 2019; Nunnally 1978) in case of a lower number of questions, the 0.6 will also be accepted. As shown in Table 2, these two parameters values for all structures stand at over 0.7 , which shows the acceptable validity of the research's structure. 
Table 2. The reliability of the questionnaire's items.

\begin{tabular}{ccccc}
\hline Variable & $\begin{array}{c}\text { Number of } \\
\text { Questions }\end{array}$ & $\begin{array}{c}\text { Composite } \\
\text { Reliability }\end{array}$ & $\begin{array}{c}\text { Cronbach's } \\
\text { Alpha }\end{array}$ & Result \\
\hline Usefulness & 4 & 0.831 & 0.742 & Confirmed \\
\hline Ease of use & 4 & 0.921 & 0.885 & Confirmed \\
\hline Subjective norms & 3 & 0.844 & 0.759 & Confirmed \\
\hline Behavioral control & 4 & 0.886 & 0.831 & Confirmed \\
\hline Attitude & 4 & 0.893 & 0.840 & Confirmed \\
\hline Intention for adoption & 2 & 0.886 & 0.748 & Confirmed \\
\hline
\end{tabular}

Results show that all the questions in current research are confirmed in different dimensions.

\subsection{Convergent Validity}

Convergent Validity is used to determine the construct validity by defining factor loading and Average Variance Extracted (AVE) (Hair Jr et al. 2016).

Table 3 shows the factor loading of the corresponding measures of each construct varying from 0.7 to 0.9 . The load value of each item on the corresponding construct is well above the recommended value of 0.7 (Fornell and Larcker 1981), indicating the proper and desirable load factor of each item on its related construct. Measures with a value of less than 0.4 can be omitted.

Table 3. The factor load of each item on its related construct and AVE.

\begin{tabular}{|c|c|c|c|}
\hline Construct & Acronym & Loading & AVE \\
\hline \multirow{4}{*}{ Perceived Usefulness } & PU1 & 0.795 & \multirow{4}{*}{0.554} \\
\hline & PU2 & 0.698 & \\
\hline & PU3 & 0.646 & \\
\hline & PU4 & 0.825 & \\
\hline \multirow{4}{*}{ Perceived Ease of use } & PEU1 & 0.883 & \multirow{4}{*}{0.744} \\
\hline & PEU2 & 0.832 & \\
\hline & PEU3 & 0.901 & \\
\hline & PEU4 & 0.832 & \\
\hline \multirow{3}{*}{ Subjective Norms } & SN1 & 0.725 & \multirow{3}{*}{0.646} \\
\hline & SN2 & 0.734 & \\
\hline & SN3 & 0.935 & \\
\hline \multirow{4}{*}{ Behavioral Control } & $\mathrm{CO} 1$ & 0.856 & \multirow{4}{*}{0.660} \\
\hline & $\mathrm{CO} 2$ & 0.751 & \\
\hline & $\mathrm{CO} 3$ & 0.848 & \\
\hline & $\mathrm{CO} 4$ & 0.790 & \\
\hline \multirow{4}{*}{ Attitude } & AT1 & 0.746 & \multirow{4}{*}{0.677} \\
\hline & AT2 & 0.794 & \\
\hline & AT3 & 0.842 & \\
\hline & AT4 & 0.903 & \\
\hline \multirow{2}{*}{ Intention for adoption } & IN1 & 0.925 & \multirow{2}{*}{0.795} \\
\hline & IN2 & 0.857 & \\
\hline
\end{tabular}

\section{Findings}

The results of descriptive statistics show that more than $90 \%$ of respondents are in the age range of 26-45 years old and have academic educations. This is an important issue since the results of 
current research can be generalized for this group of citizens who are considered to be the active population. In addition, the reason for a high percentage of master degrees (MS) in employees leads to the fact that most of them are aware of the importance/necessity of research since they have a previous academic background.

In this research, structural equation modeling (SEM) had been used for hypothesis analysis (Hair Jr et al. 2016). First, the general fitness of the model had been evaluated, then the significance of the hypothesis had been discussed. The model's fitness condition and related parameters (from AMOS) are shown in Table 4 (Shek and Yu 2014).

Table 4. Designed fitness indexes in the proposed model in AMOS software.

\begin{tabular}{cccc}
\hline Index & IFI & GFI & NFI \\
\hline Significant level of fitness & $>0.85$ & $>0.85$ & $>0.85$ \\
\hline Final model & 0.89 & 0.891 & 0.887 \\
\hline
\end{tabular}

After defining the initial model in AMOS software through SEM (Shek and Yu 2014; Blunch 2012), two variables are available at the model output, which is used for the test of the hypothesis ( $\mathrm{t}$ statistic, path coefficient). The $t$ statistic is used for estimating variables meaningfulness (CR in AMOS); if the absolute value of $t$ is more than 1.96, then the relationship is meaningful otherwise meaningless. The path coefficient shows the effects of an independent variable on a dependent one. It has a value between $-1,+1$. The absolute value of the path coefficient shows the level of impact and its direction (direct or reverse). Table 5, and Figures 5 and 6 show the software's outputs for current relationships between the model's variables.

Table 5. The values of $\mathrm{t}$ statistic and path coefficient.

\begin{tabular}{ccccc}
\hline Hypothesis No & Relationship & t Statistic & Path Coefficient & Result \\
\hline 1 & Usefulness->attitude & 3.581 & 0.27 & Confirmed \\
\hline 2 & Ease of use->attitude & 5.934 & 0.44 & Confirmed \\
\hline 3 & Control->intention & 4.469 & -0.27 & Confirmed \\
\hline 4 & Norm->intention & 0.426 & 0.02 & Rejected \\
\hline 5 & Attitude->intention & 14.07 & 0.8 & Confirmed \\
\hline 6 & Usefulness->intention & 2.065 & 0.14 & Confirmed \\
\hline
\end{tabular}

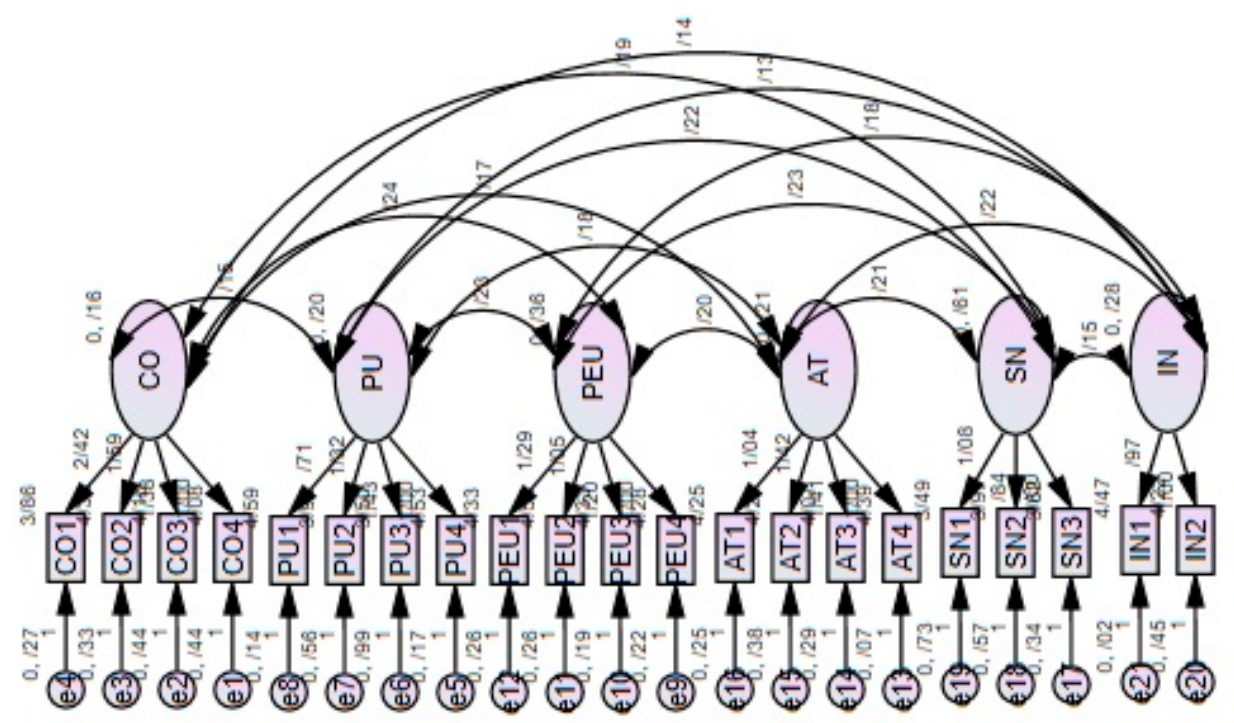

Figure 5. The fitness test for research's hypotheses. 


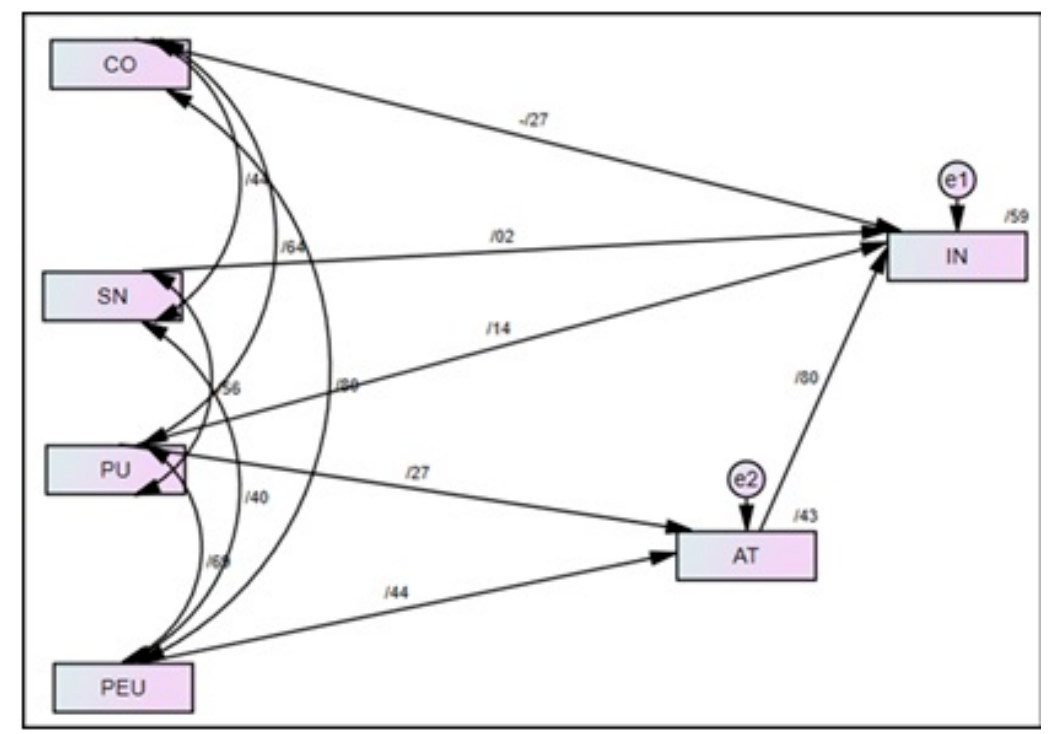

Figure 6. Path coefficients in the proposed model.

According to Table 4 and the proposed model, the following conclusions can be made:

The outcome for H1: the following hypothesis is meaningful with t statistic of 3.581 (more than $2.57 \%$ and $1 \%$ error level (Hair Jr et al. 2016)), in addition, path coefficient of 0.27 shows the relative impact of perceived usefulness on customer attitude. Thus, hypothesis 1 is confirmed.

The outcome for $\mathrm{H} 2$ : the value of $\mathrm{t}$ statistic of 5.934 (more than $2.57 \%$ and $1 \%$ error level) shows a meaningful relationship, a path coefficient of 0.44 also shows a positive and significant effect of perceived ease of use on customer attitude. So, this hypothesis had been confirmed.

The outcome for H3: $t$ statistic of 4.469 (more than 2.57\% and 1\% error level) shows that the current relationship is meaningful. Path coefficient of -0.27 reflects the partial impact of behavioral control on the development of usage intention in customers; it is a reverse impact, so the current hypothesis is modified as confirmed and reverse one.

The outcome for H4: $\mathrm{t}$ statistics is less than 1.65 (10\% error level (Hair Jr et al. 2016)), the effect of subjective norm on usage intention is not meaningful; hypothesis 4 is not confirmed.

The outcome for H5: $t$ statistic of 14.07 (more than $2.57 \%$ and $1 \%$ error level) confirms the meaningfulness of this relationship. A path coefficient of 0.8 shows the significant impact of the path coefficient on the customer's usage intention; this hypothesis has been confirmed.

The outcome for H6: $t$ statistic of 2.065 (more than 2.57 and 1\% error level), the meaningfulness of the proposed relationship is confirmed. In addition, a path coefficient of 0.14 shows there is a direct and weak relationship. Hypothesis 6 is confirmed.

\section{Discussion and Conclusions}

This study aimed to develop a proposed model for e-banking in developing countries. The proposed model was examined by conducting empirical research, including users of selected bank services. The results of the first hypothesis are in the same direction as Samar, Ghani (Samar et al. 2017), and Arif, Afshan's (Arif et al. 2016) studies. They are an instance of many domestic and international studies in this field. Results of Hypothesis 2 show that there is a meaningful relationship between perceived ease of use and customer attitude. While these two constructs are usually considered to be independent factors with no relationship, the investigation shows that in the banking field, these two constructs positively affect each other. A path coefficient of 0.44 shows the importance of perceived importance on the customer's side. The results of the second hypothesis are in the same direction as Jahangir and Begum (Jahangir and Begum 2008), Arif, Afshan (Arif et al. 2016), Khurshid, Rizwan (Khurshid et al. 2014) studies. 
Hypothesis 3 suggests that there is a significant and reverse relationship between behavioral control and usage intention; it is in contrast with the results of Takele and Sira (Takele and Sira 2013). On the other hand, it is in the same direction as Arif, Afshan (Arif et al. 2016). Credibility and trust are some aspects of behavioral control that have a negative impact on bank transactions. It is due to the cultural context and specific characteristics of developing countries. There are similar results in studies of (Arif et al. 2016), which is confirmed by the situation of the statistical population in developing countries. It seems as if banks and financial institutes require cultural investments and advertisement campaigns to gradually remind the position and importance of such factors to customers.

The fourth hypothesis was not confirmed. It means that subjective norms do not have a meaningful impact on the creation of usage intention. This outcome is in contrast with previous findings (Takele and Sira 2013; Marakarkandy et al. 2017; Safeena et al. 2013). It might be because of the sample's characteristics. Since most of the respondents in the provided sample consist of young and educated people, they are less influenced by subjective norms of friends and families, on the other hand, they care more about issues such as usefulness and ease of use.

Here the effect of attitude toward usage intention has been confirmed. A path coefficient of 0.8 is a confirmation of this influence. Credit and financial institutes, especially banks, should pay more attention to the effects of attitude on usage intention. The results of the current research show that usefulness and effectiveness have a significant and positive impact on the development of usage intention. Although this impact is not very strong (path coefficient of 0.14), since it has a direct impact on usage intention and plays its role information of an effective attitude, it has a special position. Therefore, the sixth hypothesis of this research had been confirmed too. The results of the last hypothesis are in the same direction as previous studies (Takele and Sira 2013; Safeena et al. 2013; Sharma et al. 2017). This study examines a proposed model based on a limited sample size in a specifically selected context. Also, this study did not examine the model based on the user employment background, such as employees or customers, and used the mixed sample for the analysis. To address this limitation, future studies should separately recruit different types of users and compare the results. Therefore, the proposed model should be examined in different contexts in developing countries in the future. Some directions for the future are also suggested thus:

- According to the results of this research, the role of perceived usefulness on the creation of usage intention, either directly or through the mediating role of a positive attitude in customers, is very important. So financial institutes should pay much more attention to this factor. Usefulness has an impact on usage intention through such mechanisms. It is suggested that banks and financial institutions pay more attention to the short-term benefits of customers. Methods such as discounts or rating schemes can be suggested for higher adoption toward modern banking services.

- Since the impact of attitude on usage intention is so strong, and it stays with customers for too long, it is suggested that banks perform appropriate advertising and social activities to change the attitude of the public. Revealing public and personal benefits in the long term would be effective with respect to the significant role of usefulness on the creation of a positive attitude.

- Another factor that has an impact on attitude is usage intention. It is suggested that banks and financial institutes provide modern technologies and services in a way that is operational very easily and without any complexities. New Internet and mobile applications are some of the most noticeable solutions with a simple and efficient user interface.

- The reverse impact of behavioral control on usage intention is, in fact, a confirmation toward the role of ease of use. In fact, more security layers and validation processes lead to more complexity in financial processes. It is recommended that banks pay attention to this issue during the implementation of modern technologies. Easy and electronic identification and validation processes and paying enough attention to internal security instead of assigning it to the customer are some of the most noticeable solutions in this field. 
Author Contributions: Conceptualization, F.M.E.S., and S.S. (Samad Sepasgozar); methodology, M.E.S., and S.S. (Samad Sepasgozar); software, M.E.S. and S.S. (Sharifeh Sargolzae); data curation, M.E.S.; writing-original draft preparation, F.M.E.S., and S.E.; writing - review and editing, all authors; project administration, F.M.E.S., and S.E. All authors have read and agreed to the published version of the manuscript

Funding: This research received no external funding.

Conflicts of Interest: The authors declare no conflict of interest.

\section{References}

Adjei-Bamfo, Peter, Theophilus Maloreh-Nyamekye, and Albert Ahenkan. 2019. The role of e-government in sustainable public procurement in developing countries: A systematic literature review. Resources, Conservation and Recycling 142: 189-203. [CrossRef]

Ajzen, Icek. 1991. The Theory of Planned Behavior. Organizational Behavior and Human Decision Processes 50: 179-211. [CrossRef]

Ajzen, Icek, and Martin Fishbein. 1977. Attitude-behavior Relations: A Theoretical Analysis and Review of Empirical Research. Psychological Bulletin 84: 888. [CrossRef]

Arif, Imtiaz, Sahar Afshan, and Arshian Sharif. 2016. Resistance to mobile banking adoption in a developing country: Evidence from modified TAM. Journal of Finance and Economics Research 1: 25-42. [CrossRef]

Bailey, Arlene, Indianna Minto-Coy, and Dhanaraj Thakur. 2017. IT Governance in E-Government Implementations in the Caribbean: Key Characteristics and Mechanisms. In Information Technology Governance in Public Organizations. Berlin and Heidelberg: Springer, pp. 201-27.

Becerra, Manuel, Randi Lunnan, and Lars Huemer. 2008. Trustworthiness, risk, and the transfer of tacit and explicit knowledge between alliance partners. Journal of Management Studies 45: 691-713. [CrossRef]

Bernanke, Ben S., Thomas Laubach, Frederic S. Mishkin, and Adam S. Posen. 2018. Inflation Targeting: Lessons from the International Experience. Princeton: Princeton University Press.

Blunch, Niels. 2012. Introduction to Structural Equation Modeling Using IBM SPSS Statistics and AMOS. Thousand Oaks: Sage.

Chu, Po-Young, Gin-Yuan Lee, and Yu Chao. 2012. Service quality, customer satisfaction, customer trust, and loyalty in an e-banking context. Social Behavior and Personality: An International Journal 40: 1271-83. [CrossRef]

Cronbach, Lee J. 1951. Coefficient alpha and the internal structure of tests. Psychometrika 16: 297-334. [CrossRef]

Davis, Fred D. 1993. User acceptance of information technology; system characteristics, user perceptions and behavioral impacts. International Journal of Management Machine Studies 38: 475-87. [CrossRef]

Delone, William H., and Ephraim R. McLean. 2003. The DeLone and McLean model of information systems success: A ten-year update. Journal of Management Information Systems 19: 9-30.

Fornell, Claes, and David F. Larcker. 1981. Evaluating structural equation models with unobservable variables and measurement error. Journal of Marketing Research 18: 39-50. [CrossRef]

Gregory, Gary D., Liem Viet Ngo, and Munib Karavdic. 2019. Developing e-commerce marketing capabilities and efficiencies for enhanced performance in business-to-business export ventures. Industrial Marketing Management 78: 146-57. [CrossRef]

Hair Jr, Joseph F., G. Tomas M. Hult, Christian Ringle, and Marko Sarstedt. 2016. A Primer on Partial Least Squares Structural Equation Modeling (PLS-SEM). Thousand Oaks: Sage Publications.

Hasibuan, Raya Puspita Sari, and Hery Syahrial. 2019. Analysis of the Implementation Effects of Accrual-Based Governmental Accounting Standards on the Financial Statement Qualities. Paper presented at the ICOPOID 2019 the 2nd International Conference on Politic of Islamic Development, Bandar Lampung, Indonesia, September 10.

Heng, Stefan. 2004. E-payments: Modern complement to traditional payment systems. E-Conomics Working Paper. SSRN Electronic Journal. [CrossRef]

Jahangir, Nadim, and Noorjahan Begum. 2008. The role of perceived usefulness, perceived ease of use, security and privacy, and customer attitude to engender customer adaptation in the context of electronic banking. African Journal of Business Management 2: 32.

Jamshidi, Dariyoush, and Nazimah Hussin. 2016. Forecasting patronage factors of Islamic credit card as a new e-commerce banking service. Journal of Islamic Marketing 7: 378-404. [CrossRef] 
Kaabachi, Souheila, Selima Ben Mrad, and Anne Fiedler. 2019. The moderating effect of e-bank structure on French consumers' trust. International Journal of Bank Marketing. [CrossRef]

Karunakaran, Kavunthi. 2019. Role of e-banking in current scenario. IJRAR-International Journal of Research and Analytical Reviews (IJRAR) 6: 73-76.

Khurshid, Azam, Muhammad Rizwan, and Erum Tasneem. 2014. Factors contributing towards adoption of E-banking in Pakistan. International Journal of Accounting and Financial Reporting 4: 437. [CrossRef]

Kumar, Sangeet. 2020. Advantages and challenges of e-commerce in the Indian Banking System. Studies in Indian Place Names 40: 4064-71.

Kurfall, Murathan, Ali Arifoğlu, Gül Tokdemir, and Yudum Paçin. 2017. Adoption of e-government services in Turkey. Computers in Human Behavior 66: 168-78. [CrossRef]

Kwateng, Kwame Owusu, Kenneth Afo Osei Atiemo, and Charity Appiah. 2019. Acceptance and use of mobile banking: An application of UTAUT2. Journal of Enterprise Information Management 32: 118-51. [CrossRef]

Mansour, Kaouther Ben. 2016. An analysis of business' acceptance of internet banking: An integration of e-trust to the TAM. Journal of Business $\mathcal{E}$ Industrial Marketing 31: 982-94.

Marakarkandy, Bijith, Nilay Yajnik, and Chandan Dasgupta. 2017. Enabling internet banking adoption. In Journal of Enterprise Information Management. vol. 30, pp. 263-94.

Martins, Carolina, Tiago Oliveira, and Aleš Popovič. 2014. Understanding the Internet banking adoption: A unified theory of acceptance and use of technology and perceived risk application. International Journal of Information Management 34: 1-13. [CrossRef]

McNamara, Alan J., and Samad ME Sepasgozar. 2020. Developing a theoretical framework for intelligent contract acceptance. Construction Innovation. [CrossRef]

Nunnally, Jum C. 1978. Psychometric Methods. New York: McGraw-Hill.

Osei-Kojo, Alex. 2017. E-government and public service quality in Ghana. Journal of Public Affairs 17: e1620. [CrossRef]

Petrou, Andreas. 2007. Multinational banks from developing versus developed countries: Competing in the same arena? Journal of International Management 13: 376-97. [CrossRef]

Rahman, Mahbub, Nilanjan Kumar Saha, Md Nazirul Islam Sarker, Arifin Sultana, and A. Z. M. Shafiullah Prodhan. 2017. Problems and prospects of electronic banking in Bangladesh: A case study on Dutch-Bangla Bank Limited. American Journal of Operations Management and Information Systems 2: 42-53.

Rakhmawati, Henny, and Khoiru Rusydi, and Khoiru Rusydi. 2020. Influence of TAM and UTAUT models of the use of e-filing on tax compliance. International Journal of Research in Business and Social Science (2147-4478) 9: 106-11. [CrossRef]

Ramesh, Vani, Vishal Chandr Jaunky, Randhir Roopchund, and Heemlesh Sigh Oodit. 2020. 'Customer Satisfaction', Loyalty and 'Adoption' of E-Banking Technology in Mauritius. In Embedded Systems and Artificial Intelligence. Berlin and Heidelberg: Springer, pp. 861-73.

Rifat, Afrin, Nabila Nisha, and Mehree Iqbal. 2019. Predicting e-Tax Service Adoption: Integrating Perceived Risk, Service Quality and TAM. Journal of Electronic Commerce in Organizations (JECO) 17: 71-100. [CrossRef]

Rigopoulou, Irini D., Ioannis E. Chaniotakis, and John D. Kehagias. 2017. An extended technology acceptance model for predicting smartphone adoption among young consumers in Greece. International Journal of Mobile Communications 15: 372-87. [CrossRef]

Safeena, Rahmath, Hema Date, Nisar Hundewale, and Abdullah Kammani. 2013. Combination of TAM and TPB in internet banking adoption. International Journal of Computer Theory and Engineering 5: 146. [CrossRef]

Samar, Samar, Ghani Mazuri, and Alnaser Feras. 2017. Predicting customer's intentions to use internet banking: The role of technology acceptance model (TAM) in e-banking. Management Science Letters 7: 513-24.

Scherer, Ronny, Fazilat Siddiq, and Jo Tondeur. 2019. The technology acceptance model (TAM): A meta-analytic structural equation modeling approach to explaining teachers' adoption of digital technology in education. Computers E Education 128: 13-35.

Sedik, Tahsin Saadi, Sally Chen, Tarhan Feyzioglu, Manuk Ghazanchyan, Souvik Gupta, Sarwat Jahan, and Juan Manuel Jauregui. 2019. The Digital Revolution in Asia and Its Macroeconomic Effects. Tokyo: Asian Development Bank Institute, No. 1029.

Sepasgozar, Samad M. E., Martin Loosemore, and Steven R. Davis. 2016. Conceptualising information and equipment technology adoption in construction A critical review of existing research. Engineering, Construction and Architectural Management 23: 158-76. [CrossRef] 
Sepasgozar, Samad M.E., Sara Shirowzhan, and Cynthia Changxin Wang. 2017. A Scanner Technology Acceptance Model for Construction Projects. Procedia Engineering 180: 1237-46. [CrossRef]

Sepasgozar, Samad M.E., Scott Hawken, Sharifeh Sargolzaei, and Mona Foroozanfa. 2019. Implementing citizen centric technology in developing smart cities: A model for predicting the acceptance of urban technologies. Technological Forecasting and Social Change 142: 105-16. [CrossRef]

Shankar, Amit, and Charles Jebarajakirthy. 2019. The influence of e-banking service quality on customer loyalty. International Journal of Bank Marketing. [CrossRef]

Sharma, Sujeet Kumar, Srikrishna Madhumohan Govindaluri, Saeed Al-Muharrami, and Ali Tarhini. 2017. A multi-analytical model for mobile banking adoption: A developing country perspective. Review of International Business and Strategy 27: 133-48. [CrossRef]

Shek, Daniel T.L., and Lu Yu. 2014. Confirmatory factor analysis using AMOS: A demonstration. International Journal on Disability and Human Development 13: 191-204. [CrossRef]

Shirowzhan, Sara, Willie Tan, and Samad M.E. Sepasgozar. 2020. Digital Twin and CyberGIS for Improving Connectivity and Measuring the Impact of Infrastructure Construction Planning in Smart Cities. ISPRS International Journal of Geo-Information 9: 240. [CrossRef]

Soeng, Reth, Ludo Cuyvers, and Morarith Soeung. 2019. E-commerce Development and Internet Banking Adoption in Cambodia. Developing the Digital Economy in ASEAN, 176-99. [CrossRef]

Syniavska, Olga, Nadiya Dekhtyar, Olga Deyneka, Tetiana Zhukova, and Olena Syniavska. 2019. Security of e-banking systems: Modelling the process of counteracting e-banking fraud. Paper presented at the SHS Web of Conferences, Sakarya, Turkey, June 19-22.

Takele, Yitbarek, and Zeleke Sira. 2013. Analysis of factors influencing customers'intention to the adoption of e-banking service channels in Bahir Dar City: An integration of TAM, TPB and PR. European Scientific Journal 9: 403-17.

Tam, Carlos, and Tiago Oliveira. 2017. Understanding mobile banking individual performance. Internet Research 27: 538-62. [CrossRef]

Twizeyimana, Jean Damascene, and Annika Andersson. 2019. The public value of E-Government-A literature review. Government Information Quarterly 36: 167-78. [CrossRef]

Ullah, Fahim, M.E. Sepasgozar Samad, and Siddra Siddiqui. 2017. An Investigation of Real Estate Technology Utilization in Technologically Advanced Marketplace. Paper presented at the 9th International International Civil Engineering Congress (ICEC-2017) “Striving Towards Resilient Built Environment”, Karachi, Pakistan, December 22-23.

Vakulenko, Yulia, Poja Shams, Daniel Hellström, and Klas Hjort. 2019. Service innovation in e-commerce last mile delivery: Mapping the e-customer journey. Journal of Business Research 101: 461-68. [CrossRef]

Yue, Xiao-Guang, Xue-Feng Shao, Rita Yi Man Li, M. James C. Crabbe, Lili Mi, Siyan Hu, Julien S. Baker, and Gang Liang. 2020. Risk management analysis for novel Coronavirus in Wuhan, China. Journal of Risk Financial Management 13: 22. [CrossRef]

Yue, Xiao-Guang, Xue-Feng Shao, Rita Yi Man Li, M. James C. Crabbe, Lili Mi, Siyan Hu, Julien S. Baker, Liting Liu, and Kechen Dong. 2020. Risk Prediction and Assessment: Duration, Infections, and Death Toll of the COVID-19 and Its Impact on China's Economy. Journal of Risk and Financial Management 13: 66. [CrossRef]

(C) 2020 by the authors. Licensee MDPI, Basel, Switzerland. This article is an open access article distributed under the terms and conditions of the Creative Commons Attribution (CC BY) license (http://creativecommons.org/licenses/by/4.0/). 